\title{
A Review of a Successful Unsubsidized Market-Based Rural Solar Development Initiative in Laikipia District, Central Kenya
}

\author{
O. Wambuguh ${ }^{*}$ \\ Environmental Health Sciences, California State University, USA
}

\section{Article history:}

Received August 20, 2013 Received in revised form Sept. 18, 2013 Accepted September 27, 2013 Available online

\begin{abstract}
The development of renewable energy technologies (RETs) in many areas far from grid-based electricity have primarily involved solar photovoltaics (SPVs) which tap solar radiation to provide heat, light, hot water, electricity, and cooling for homes, businesses, and industry. A study on RETs took place in the Wiyumiririe Location of Laikipia District (north-central Kenya), a rich agricultural region. To explore this solar initiative in such a remote part of the country, a purposive randomized convenience sample of 246 households was selected and landowner interviews conducted, followed by field visits and observations. Although more than half of the households visited had SPV installations, solar energy was found to contribute only $18 \%$ of household estimated total energy needs; most residents still primarily relying on traditional energy sources. Several types of solar panels of different capacities and costs were utilized. Many landowners had at least one or two rooms using solar energy for household lighting, for appliance charging and to power radio and television. Almost all respondents appreciated that solar energy was clean renewable energy that greatly improved household living conditions; gave them some prestige; was easy to use and maintain; and was available year around. Although such significant benefits were associated with SPVs, only about $40 \%$ of residents interviewed were somehow satisfied with its development. Respondents expressed specific developmental initiatives that were closely associated with the availability of solar energy. Nevertheless, a number of challenges were raised associated with SPVs primarily investment capital and equipment costs and maintenance. As solutions to capital building will not solely rely on subsidies or individual farmer inputs, strategies must be found to mobilize the essential and tested tools for success including sustainable capital generation, building local institutions and capacities that integrate rural people, local participation in rural development activities and public education and training.
\end{abstract}

Keywords: appliance charging,battery,development initiatives, household lighting, landowners,solar energy, SPVs, solar equipment and accessories

\section{Introduction}

In a world dominated by pertinent environmental issues like global warming, loss of biodiversity, dwindling fossil-fuel supplies, loss of top soil, desertification and declining air and water quality; rethinking our interactions with the environment and adopting new strategies of life is becoming a matter of necessity for our own survival on this planet particularly in this century (Hajat et al. 2010; Pandey et al. 2012). According to Chua and Oh, "solar energy is projected to supply $30 \%$ of the world's energy demand by 2050 , and create an industry far bigger than the global automotive industry... and focused to provide about $64 \%$ of the electricity supply in 2100 " (2012, p.569). This wave of change is system-wide fuelled by five meta-trends that some believe (e.g. Scholz 2006) are profoundly changing the world including: cultural modernization, information technology and universal connectivity, economic globalization, transactional transparency and social adaptation. (Solangi et al. 2011). In September 2000 at the general assembly of the United Nations in New York, world leaders agreed on a set of eight well-defined and ambitious development targets to be reached by the year 2015 . These UN Millennium Development Goals (MDGs) have brought development concerns back to the forefront of the political agenda and provided a common framework 
and guidance for action in development cooperation. Those include, but not limited to research and development of Renewed Energy Technologies (RETs), reforestation programs, greenhouse gas emissions reduction, aquifer protection and biodiversity protection (Brent \& Kruger 2009; Hajat et al. 2010). According to Martinot (2001), renewable energy sources made their first real entry to the international scene in 1970s when the two worldwide oil crises occurred. Discussions about RETs have occurred in many international forums including UN Conference on the Environment in Nairobi (1981), Rio de Janeiro (1992), World Summit on Sustainable Development in Johannesburg (2002); and lately, the UN Conference on Sustainable Development again at Rio de Janeiro (2012, referred simply as "Rio+20"). As a result, the development of RETs has increasingly received much attention in developing nations by host governments, multi-lateral donors, non-governmental organizations and increasingly often, by individual consumers (BrewHammond, 2010; Hajat et al. 2010; Moosavian et al. 2013).

In terms of energy use cooking, heating and lighting are by far the highest consumers of energy in developing countries (Barnes \& Halpern 2000; Osuagwu et al. 2011; Zhao et al. 2013). There is also a major distinction between energy types used in both urban and rural areas in many developing nations. While those living in major urban centres primarily rely on grid-based electricity, petroleum products like kerosene and liquefied petroleum gas (LPG) and to a lesser extent bio-fuels like charcoal and wood; most rural dwellers primary sources of energy are bio-fuels (wood, charcoal, crop residues, and saw dust) and petroleum products (kerosene and to lesser extent LPG). However, Louineau et al. (1994) found out that urban-rural energy source differences were not as discrete, reflecting a continuum such that smaller to mid-sized towns depended more on bio-fuels than larger ones. The study also found a difference in energy source choice between the rich and the poor particularly in urban settings: the richer urban households had more space heating/cooling and lighting with more usage of electrical appliances and more LPG use than rural households that depended more on charcoal and wood (McGranahan \& Kaijser 1993; Chua \& Oh 2011).

On the energy front, developing RETs based on hydrogen, wind and solar power has accelerated in many parts of the world particularly in many parts Europe, North America, and China (Green 2000; Mekhilef et al. 2011). This expansion has also accelerated research and development of sustainable development programs throughout the developing world including India, Indonesia, Middle East, Africa and South America. Although not at all immune from environmental concerns like air pollution, biodiversity loss, hazardous waste production, and socio-cultural issues, development of RETs allows the avoidance of many other serious environmental problems connected to fossil fuels and nuclear energy (Arvidson 1994; Solangi et al. 2011). Further, Arvidson (1994) notes that there are several factors that may hamper rapid development of RETs in developing countries including lack of infrastructure, government subsidies, credit facilities, lack of appropriate local institutions, enabling government policy and local consumer attitudes. Within the last two decades increasing use of such alternative energy systems has dominated many nations in the developing world particularly in rural areas (Acker \& Kammen 1996; DME 1998; Abavana 2000; Mulugetta, Nhete \& Jackson 2000; Martinot 2001; Diarra \& Akuffo 2002; Duke, Jacobson \& Kammen 2002; Jacobson 2007; Hajat, Banks, Aiken \& Shackleton 2010; Chua \& Oh 2011; Mekhilef et al. 2011; Solangi et al. 2011; Moosavian et al. 2013). The common strategy has been to develop a framework through which electric services based on solar energy can be provided in rural areas in a financially and socially sustainable manner (Kalumiana 2002; Brent \& Kruger 2009).

Recognizing the need for energy services in development not only to cater for basic needs, but also for economic growth, education and health services, the East African Countries of Kenya, Tanzania and Uganda have started to develop a comprehensive energy access strategy built on four specific targets which are seen as a necessary complement for achieving the MDGs by 2015 (Scholz 2006). Weggoro (2006) states that the recognition of the fundamental role modern energy services play in achieving the MDGs, the East African Community (EAC) has formulated a strategy for how to increase access to almost 50 million people in the region by 2030. This target, Weggoro (2006) states, is very ambitious considering that about $90 \%$ of the East African population today relies on traditional biomass for cooking. Achieving a stable and affordable supply of this magnitude is a major task involving infrastructural development, creation of financing mechanisms, implementation of new household appliances competing with traditional means of cooking, and creating the right mix of energy carriers to avoid supply dependencies (Arvidson et al. 1999; Saghil 2002; Weggoro 2006; Jacobson 2007; Brew-Hammond 2010).

Rural electrification rates are very low at between $1 \%$ and $4 \%$ of the households; and only about $38 \%$ of the urban households in the EAC countries are connected to the national electricity grid. The annual grid extension rates remain marginal due to the high pace of urban growth in this region. Hence, there is a continued reliance on traditional biomass such as wood, charcoal or crop residues to meet energy needs. (Scholz 2006; Hajat et al. 2010). The target, Mehlwana (2002) cautions, should not be too much emphasis on disseminating technologies and playing the "numbers game" in which the numbers of households with electricity is the most important statistic: the focus 
should be meeting the needs of rural households in a meaningful and sustainable manner. The emergence of a market-based solar PV technology in many rural areas of Africa has been cited as resulting from a decline in donor-funded rural electrification infrastructure that dominated energy development in the period before the late1980s. In those days, centralized solar panel stations relying on a large array of photovoltaics were built at costs of between US\$200,000-300,000 but later proved unreliable and expensive to maintain (Horlocks 2003). Starting from the late 1980s and 1990s energy developmental attention focused on economic liberalization and market-based approaches that greatly fuelled and expanded private sector participation. (Jacobson 2004; Jacobson 2007; Hajat, Banks, Aiken \& Shackleton 2010; Brew-Hammond 2010; Mekhilef et al. 2011; Zhao et al. 2013).

This study explored solar energy development (hereafter SPV) in Wiyumiririe Location of Laikipia District of north-central Kenya. A major objective of the study was evaluate the development of SPV in this small-scale farming community, landowner solar energy attitudes, solar energy use, associated benefits and community impact, and the main challenges to its development. The specific objectives of the study were to: 1) find out the extent of solar energy use (in exclusion or in addition to other sources of energy) by landowners in the region; 2) find out the attitudes of farmers towards solar energy technology; and 3) evaluate the socio-economic, developmental and environmental impact of this developing technology on rural livelihoods.

\section{Study Area and Methods}

This study took place in the Wiyumiririe Location of Laikipia District in north-central Kenya (Fig. 1), a rich farming region in the eastern slopes of the Aberdares Range. The District comprises a plateau located east of the Great Rift Valley between latitudes $0017^{\prime} \mathrm{S}-0045^{\prime} \mathrm{N}$ and longitudes $36010^{\prime} \mathrm{E}$ - $3703^{\prime} \mathrm{E}$ hemmed in the west by the Aberdares Range, to the south and south-east by Mt. Kenya, and to the east by the Mukogodo hills. It averages in altitude $2000 \mathrm{~m}$ but rises to over $2500 \mathrm{~m}$ on the Aberdares slopes and $2250 \mathrm{~m}$ on the Mt. Kenya slopes. With an area of approximately $9723 \mathrm{~km} 2$ most of Laikipia is low country with numerous broad and generally grassy volcanic ridges cut into by two major rivers Narok and Ewaso Nyiro with various tributaries flowing down from the Aberdares Ranges and Mt. Kenya. These rivers serve as perennial water sources to the livestock ranching activities that predominate in Laikipia district. Landuse in Laikipia shows great diversity in origin, appearance and impact on society and ecosystem, and its different modes form a complex that with further examination reveals some of the most fundamental changes that have taken and continue to -

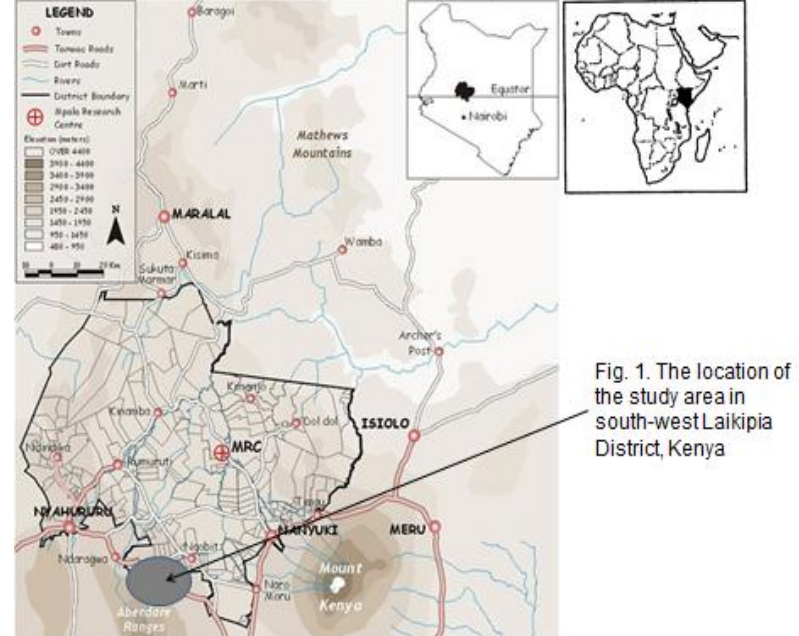

Fig. 1 The location of the study area in south-west Laikipia District, Kenya

take place in the utilisation of land in post-colonial Kenya. The dominant landuse is large-scale ranching under non-African ownership (between $50-70 \%$ of district); African ownership (7.8\%) and state ownership $(8.5 \%)$. Small-scale farming that arose as a result of government resettlement schemes soon after political independence in 1963 today comprises about $5-10 \%$ of the district. Pastoralism which is more confined in the north and the north-eastern parts comprises about 13\% of the District.

The extent of SPV development in the region was obtained through an initial preliminary survey undertaken in the area in consultation with local community leaders, developmental facilitators and small-scale landowners. From this survey, it was gathered that SPV development was generally random and localized in the region, necessitating the need for a purposive randomized convenience sample selection (as explained by Chaudhuri 1992; Scheaffer et al. 1996). Of the 246 households selected, 129 had incorporated SPVs but 117 had not. The selected households were then visited for field observations of solar development and landowner interviews using a previously prepared questionnaire. Only adults 18+ years were interviewed at each homestead, males or females. Male landowners were found to be forthcoming and informed with information about solar energy than females. During the surveys and interviews, the extent of solar energy development, landowner solar energy attitudes, developmental incentives, solar energy impacts on socio-economic development, and the environment were recorded.

\section{Results and Discussion}

\subsection{Landowner Energy Sources}

Although solar PV development in Wiyumiririe appears widespread over a large region, its distribution is random and does not seem to follow an easily 
predictable pattern anywhere in Laikipia District. This is expected bearing that SPV development in the region is market-based and unsubsidized depending purely on individual initiatives. More than $90 \%$ of the farmers in this region settled through government assisted landbuying schemes where individuals bought shares in those companies depending on their ability. The more shares one bought, the bigger the size of land the individual eventually got. This brought about the current mix of landowners with differing socioeconomic capabilities. Although all households visited had solar PV installations, this new source of energy contributed only $18 \%$ of their total energy needs (Table 1).

This minimal contribution is attributed to the low capacities of the solar panels used by most households (Fig. 2) and high upfront capital costs. If this is to change, then high capacity solar panels are needed which can supply electricity to more rooms in the main house, to more than one house per household and still be available for other important uses like electronic appliances and cell phone charging. As Khennas (2002) and Jacobson (2007) note, solar panels are only one part of a solar PV system - other costs termed by Foley "balance of system costs" include mounting, wires, switches, batteries, ballasts, control systems, special low-power lights and other equipment. According to Duke, Jacobson and Kammen (2002) those solar components are usually more decisive for the economies of the system than the solar panel itself.

Many landowners expressed a "catch-22" situation where they were caught up with low efficiency solar panels and batteries which cannot be returned to seller to help defray costs towards new high capacity ones with the associated battery (for instance, exchanging a $14 \mathrm{~W}$ panel for a $100 \mathrm{~W}$ one). The part played by the market in determining what solar equipment was installed by households was important: some of the problems with many landowners arose from what the market made available to them a few years ago and are now stuck with them. With advances in solar technology today, better, affordable and more efficient models are now available.

Table 1.

Current Energy Sources in Wiyumiririe Location, Laikipia District $(\mathrm{n}=129)$

\begin{tabular}{lccl}
\hline Energy Source & $\#$ & $\begin{array}{c}\text { \% Contribution } \\
\text { to Total Energy } \\
\text { Budget }\end{array}$ & Primary Uses \\
\hline $\begin{array}{l}\text { Biomass } \\
\text { (wood \& } \\
\text { charcoal) }\end{array}$ & 129 & 55 & Cooking/Heating \\
$\begin{array}{l}\text { Petroleum } \\
\text { (kerosene) }\end{array}$ & 129 & 15 & Lighting \\
$\begin{array}{l}\text { Petroleum } \\
\text { (cooking gas) }\end{array}$ & 49 & 8 & Cooking \\
$\begin{array}{l}\text { Solar PV } \\
\text { Dry-cell }\end{array}$ & 129 & 18 & Lighting/Appliances \\
batteries & 129 & 4 & Flashlights/Radios \\
\hline
\end{tabular}

However, changing the economic perceptions of societies such as those in this study to accept the fact that advances in technology do affect how we all live anywhere on the planet does not happen overnight (that is, they should embrace material consumerism as an economic reality). This is particularly so for communities whose sources of income are largely unpredictable and inadequate. A program like the one currently adopted by cell-phone companies in places like the United States which agree to accept older phones as part payment towards newer ones with better capabilities might be what is required for these households. A donor agency that can provide such swaps by accepting old panels for new ones on a grant basis or perhaps provide easy credit terms for those landowners with them could make a big difference in such communities (Kjellström 2005; Jacobson 2007).

As seen on Table 1, landowners used various types of energy to power their domestic household needs that include household lighting, cooking, heating, powering appliances and flashlights. Even with solar energy supplementing energy needs, most households still highly depended on biomass (primarily firewood and charcoal for heating and cooking), kerosene for lighting, natural gas for cooking and dry-cells to power flashlights used for household security (Arvidson et al. 1999; Ellegård et al. 2003; Gustavsson 2002, 2003; Molares 2002; Jacobson 2007). Considering the future energy options and socio-economic conditions of most respondents, it is unlikely that the overwhelming reliance on biomass as the primary source of energy for cooking and heating will be replaced anytime soon. Even with more efficient high-capacity solar panels (which only a small fraction of the households will afford) or grid-based electricity which will require electric stoves (that only a few can afford), biomass will continue to meet the day-to-day energy needs in the foreseeable future. Today, biomass contributes about $55 \%$ of the average total energy needs of households visited (see Table 2).

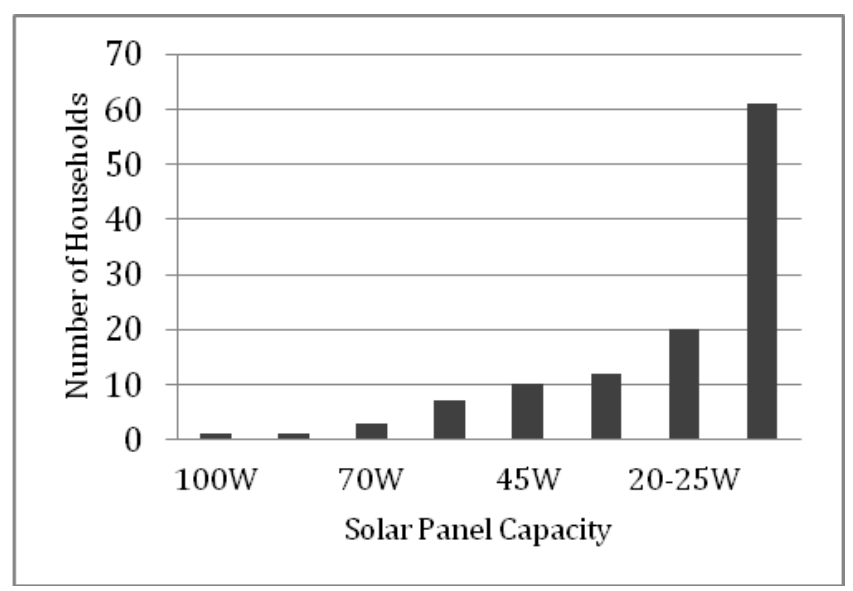

Fig. 2 Number of Households and Solar Panel Capacities Used in Wiyumiririe Location $(\mathrm{n}=129)$ 
Table 2.

Solar Panel and Battery Costs in Wiyumiririe Location ( $\mathrm{n}=129)$

\begin{tabular}{cccc}
\hline $\begin{array}{c}\text { Capacity } \\
\text { (W) }\end{array}$ & US\$ & $\begin{array}{c}\text { Battery } \\
\text { Recommended } \\
\text { (Amperes) }\end{array}$ & US\$ \\
\hline 150 & 1091 & 200 & 254 \\
100 & 727 & 150 & 189 \\
85 & 667 & 150 & 189 \\
70 & 485 & 100 & 129 \\
50 & 402 & 70 & 109 \\
45 & 318 & 70 & 109 \\
$30-37$ & 273 & 50 & 88 \\
$20-25$ & 189 & 50 & 88 \\
$14-15$ & 98 & 32 & 50 \\
3 & 61 & None & None \\
1.5 & 38 & None & None \\
\hline
\end{tabular}

It appears that with increased solar or grid-based electricity, the immediate household energy budget effect is the replacement of kerosene as the main energy source for lighting, left to be used only during emergencies. The role of cooking gas currently contributing only $8 \%$ of total domestic energy needs and which is stored in pressurized containers as liquefied petroleum gas (LPG) will continue to be minimal in communities such as this one. One reason for this is the costs of gas cylinders, cost of gas stoves, and the cost of delivering empty containers to major urban centres for fill-up. In this area for instance, the nearest centre for cylinder exchange would take a landowner almost the whole day to and fro using public transport. Finally, use of dry-cell batteries in flashlights is in this area primarily for security and emergencies will never cease. Households are still a big target for burglaries involving household goods, livestock theft and solar equipment any hour of day or night. Many landowners mentioned the need for a caretaker within the household premises should they be planning to spend the day or night out.

\subsection{Landowner SPV Infrastructure}

Several types of solar panels of different capacities and costs are utilized by landowners in the area (Table 2 ). The most common solar panels with 61 landowners $(47 \%, n=129)$ were within the $14-15 \mathrm{~W}$ range which were priced to just under US\$100 (Fig. 2 and Table 2). This differs markedly with average solar panel sizes you find in places where we have Energy Service Companies (ESCOs), reported by Ellegård and Nordström (2001) to be $50 \mathrm{~W}$. While the 14-15W size provides enough solar energy for a maximum lighting of 2-3 rooms, 3 hours TV viewing, 12 hour radio use and unlimited cell-phone charging capacity, many households with it raised a number of concerns. One, it limited their household lighting capacity as many preferred light in the kitchen (usually a room adjacent to the main house) in the evenings; light in the bedrooms, living room and other rooms in the main house.

As many had grown-up children (some with families of their own) who stayed in adjacent smaller houses to the main house when they visit during the holidays, many landowners expressed the desire for a higher capacity solar panel. Second, many wanted panels with somewhat unrealistic power options like boiling kitchen water, although most were happy to just get warm water for bathing, affordably.

Third, most households stated the need for security lighting at night. Only those with capacities over $45 \mathrm{~W}$ would provide such capabilities and as data from this community shows those were also the least affordable. This appears to be the case for other areas too (for example studies by Ellegård \& Nordström 2001; Gustavsson 2002, 2003; Rockström, et al. 2005; Jacobson 2007; Chua \& Oh 2012; Zhao et al. 2013).

As solar panel capacity increased from $20 \mathrm{~W}$ to $50 \mathrm{~W}$, the ability to light more rooms, have more flexibility in TV viewing, unlimited radio use and cellphone charging increased tremendously and most households with at least 20W mostly expressed some satisfaction with their SPV. However, even those households in this group expressed the need to have panels in the range of $70-100 \mathrm{~W}$ priced in excess of US $\$ 500$. According to solar panel vendors, most panels had an estimated useful life of about 25 years (Ellegård \& Nordström 2001; Liu et al. 2010; Moosavian et al. 2013 study), a double-edged sword for most landowners with small capacity panels. On the positive side is the long, least maintenance and dependable life of the panel; on the other, is their desire to replace old solar panels with more efficient high-capacity panels. If this was not an option due to cost, some respondents opted to buy an extra low-capacity panel to serve a bigger high-capacity battery.

Depending on the capacities of the solar panels used, there were also a variety of batteries capacities recommended (Table 2). With most households within the $14-15 \mathrm{~W}$ solar panels range, the 32 amps battery dominated most households and cost about US\$65. Some households even had two batteries of the same amperage served by the same panel; however, they did not store enough power to cater for domestic light usage in the evenings (especially if powered by solar panels within the 14-15W range). As noted for the higher end solar panels (70-150W), batteries associated with them (100-150 amps) cost the few households (4\%, Table 2 ) that could afford them between US\$150190. Many households appreciated the long useful life of solar batteries (irrespective of size) estimated to be about 4-5 years with annual acid-flushing/charge boosting maintenance. However, a few respondents (16.3\%; $n=129)$ had very different solar battery experiences - with some ceasing functioning after as little as 8 months, a year or at most two years and requiring replacement. Those poor batteries were attributed to unscrupulous merchants who also gave annual warranties that did not replace or adequately repair malfunctioning batteries. After repeated frustrations, respondents end up disposing such batteries to local outlets that buy a failing US\$ 65 - 
Table 3.

Costs of associated solar equipment and accessories in Wiyumiririe Location

\begin{tabular}{lcc}
\hline \multicolumn{1}{c}{ Type } & US\$ & \% \\
\hline Surge Controller & 26 & 3 \\
Inverter & 72 & 5 \\
Solar flashlight & 35 & 24 \\
Solar Lantern & 98 & 7 \\
\hline
\end{tabular}

Table 4.

Seller Solar Packages ${ }^{1}$ available to household in Wiyumiririe Location

\begin{tabular}{lc}
\hline \multicolumn{1}{c}{ Type } & US\$ \\
\hline Four Lights & 417 \\
Six Lights & 572 \\
Eight Lights & 714 \\
Ten Lights & 970 \\
Twelve Lights & 1268 \\
\hline
\end{tabular}

${ }^{1}$ Packages include: solar panel, battery, charging cables, lights, switches, terminal connectors, switch connectors, nails and labour

-battery for a meagre US $\$ 1.50$ (a 98\% loss). This has left those respondents with very unhappy experiences and mixed feelings about solar power, opting to invest in grid-based electricity despite the long waiting period. Similar findings were also reported by Jacobson (2007).

Some other battery challenges found in some households and reported by others (Foley 1991; Jacobson 2007; Hajat et al. 2010; Liu et al. 2010; Mekhilef et al. 2012; Pandey et al. 2012; and Zhao et al. 2013) are one; the use of car batteries not designed for frequent deep charging and discharge cycles - therefore lasting only a year or so at most. Two, excessive charging and discharging and neglecting to top up with distilled water which results in rapid failures. In addition to the basic solar equipment that includes a panel, battery, wiring, switches and bulbs, a number of other optional accessories were in the market (Table 3). It is not surprising that only the solar flashlight was owned by about a quarter of the respondents (24\%) with all the others owned by less than $10 \%$ of the households visited. It appears that many households factored a solar flashlight's convenience and flexibility of use both indoors and outdoors before incurring its cost.

A number of solar vendors had promotions and packages available that included everything needed to install solar energy in a household (Table 4). The minimum package with four lights cost a little over US $\$ 400$ and the most expensive with 12 lights cost about US $\$ 1,268$.

Due to the relatively steep pricing of these packages, many respondents interviewed preferred to purchase their solar equipment separately and pay for the labour required on their own using local electricians whose charges were more affordable (see next section).

\subsection{Internal Dwelling Wiring: Needs and Extent}

The number of rooms with wiring completed for lighting and with television, radio and cell-phone charging receptacles varied for each landowner (Fig. 3).
While most households (40\%) had only two served rooms, about one-third (32\%) had only one room served and about a fifth $(21 \%)$ three rooms.

The percentages decreased further as the number of rooms served within the main house increased from four to six. Most households contracted local electricians for household wiring and material needs at costs ranging from US\$34-178 (Table 5).

Although relatively modest electrical work that requires no maintenance (except for bulb replacement), most landowners stated that these costs were significant as the number of rooms increased as Green (2000) found. Though expressing the desire to wire the whole house the majority of landowners preferred that at a minimum, and in order of priority to have the living room, bedroom and kitchen completely wired for solar (Table 6).

This preference is expected with the living room being the centre of most household appliances (TV, radio and cell phone charging). Apart from the time family members spent in the kitchen preparing meals (predominantly the household mother's responsibility)

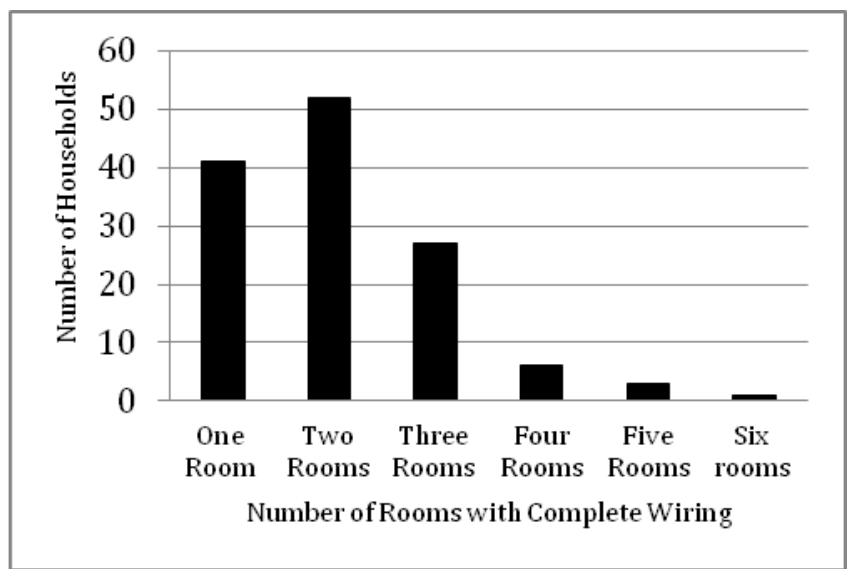

Fig. 3 Number of Rooms wired for Solar Power per Household in Wiyumiririe Location $(n=129)$

Table 5.

Number of Rooms wired for Solar Power per Household in Wiyumiririe Location $(n=129)$

\begin{tabular}{ll}
\hline Number of Rooms & Cost + Materials (US\$) \\
\hline One & 34 \\
Two & 70 \\
Three & 98 \\
Four & 119 \\
Five & 139 \\
Six & 178 \\
\hline
\end{tabular}

Table 6.

Room Type and Landowner Solar Wiring Priority in Wiyumiririe Location $(\mathrm{n}=129)$

\begin{tabular}{lccc}
\hline \multicolumn{1}{c}{ Room } & Ranking & Number & \% \\
\hline Living Room & 1 & 129 & 100 \\
Parent's Bedroom & 2 & 106 & 82 \\
Kitchen & 3 & 72 & 56 \\
Children's Bedrooms & 4 & 61 & 47 \\
Guest Bedroom & 5 & 32 & 25 \\
Storage Room & 6 & 23 & 18 \\
Other Rooms & 7 & 4 & 3 \\
\hline
\end{tabular}


school children spent their evening time doing homework in the living room. In households where there were no school children, fathers spent early evenings with their wives in the kitchen (for company rather than to help prepare meals, with radio on for news and entertainment) and later the couple relaxed in the living room to watch TV. The main bedroom is where couples spent late evening and the rest of night.

Despite the kitchen's central role as the site for household meals preparation, data in Table 6 seems to support a puzzling finding: that most households do not consider the kitchen a priority for solar lighting purposes. This can be explained by three reasons. One, time spent in the kitchen preparing the evening meal whether by the household mother or the couple is relatively short and a kerosene lamp adequately caters for lighting. Two, in communities such as this one in Wiyumiririe, traditional responsibilities that are naturally performed by household mothers including household cleaning and washing, cooking, gathering firewood and water plus taking care of children receive least priority. To highlight this oddity in many households, fathers will often relax charting with their friends in (solar lighted) living rooms enjoying local beer as they watch TV waiting for dinner from the (poorly-lighted) kitchen. All other rooms including children bedrooms do not appear to most respondents interviewed as priorities in households plagued by tight budgets and competing needs. After all, the need for light in kids' bedrooms is presumed minimal because children will have spent most of their evening time in the living room doing homework and afterwards relaxing to watch TV or listen to the radio. Three, the kitchen in most rural households is separate from the main house - usually a single and rarely two rooms (one a store for food, firewood and charcoal). Being separate from the main house seems to relegate it to relatively lower priority status in most households.

\subsection{Landowner Solar Energy Uses}

a) Overall Solar Energy Benefits

All respondents agreed that among other benefits light provision and appliance charging were perhaps the most important (Fig. 4). Light was used for evening activities in the living room, bedrooms, kitchen and household compound security. Appliance charging included cell phones and rechargeable flashlights which a number of landowners used for security (Gustavsson 2002, 2003; Horlocks 2003; Jacobson 2007). Almost all respondents (97\%) appreciated that solar energy was clean renewable energy that greatly improved household living conditions and gave them some prestige (65\%); was easy to use and maintain (93\%) and was available year-around (88\%).

The importance of staying informed on daily basis with news and entertainment which included watching TV programming and video in this community can be judged from the proportion who appreciated this solar benefit (82\%, Fig. 4). Ellegård \& Nordström (2001) report similar findings in southern Africa.

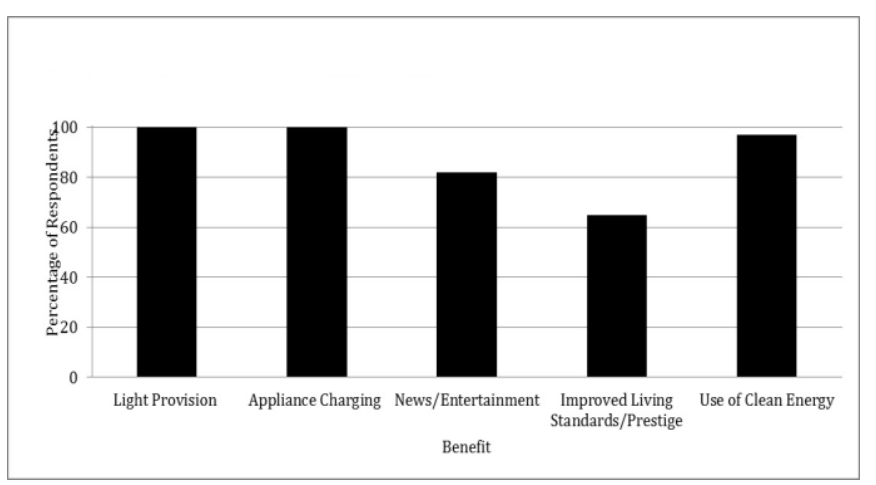

Fig. 4 Solar PV Benefits in Wiyumiririe Location $(\mathrm{n}=129)$

\section{b) House Lighting and Cell Phone Charging}

While all landowners stated that house lighting and radio tuning were the most popular solar energy uses, according to landowner estimated energy use budgets, house lighting, among other solar energy uses commands a lion's share of the total solar energy generated by most households, followed by radio tuning and cell phone charging. It also ranked as the top priority for all landowners (Table 7).

A similar solar power usage profile was also reported by Martinot and Ramankutty (2000). The need for household lighting in rural areas like Wiyumiririe where rural grid-based electrification programs are yet to be developed is emphasized by the priority given to it by households.

Apart from securing substantial savings in kerosene purchases, most respondents felt the use of solar lighting also made their households look more modern, somehow raising their standard of living, a result many households were happy about (Fig. 4). Another added benefit for those with working children in urban centres was when the latter visited during the school holidays particularly in December (traditionally the longest school holiday of the year and also a month of festivities when most Kenyan families rejoin) when the availability of solar lighting to the united families allow more enjoyment and easier living for everyone.

With many national telephone networks in many developing countries poorly designed, inefficient and corrupt, mobile phone corporations have sprung to replace many landlines except in public offices. According to Stockholm Environmental Institute (2010) more cell phone connections have turned on in Africa in the last five years than landline connections in the past century. In Kenya, this has seen the emergence of three main cell phone companies as of 2008: Safaricom (60\% state-owned), Celtel (100\% private) and Telkom Kenya (100\% state-owned). As expected, cell phone charging is a matter that cannot be overemphasized in the rural areas far from grid-based electricity. It is so vital to many rural folk that for the $85 \%$ of the respondents who reported owning a cell-phone, the ability to charge 
their phone sets at the convenience of their own homes, outmatched all other solar energy uses.

Many households owned more at least two cell phones (for the two parents) and if working children were within the household, the number adds up to perhaps five phones. Many landowners stated it that although cost them a minimal amount of only US $\$ 0.35$ to charge one cell phone (maximum of US\$1.75 for five phones) at a grid-connected shop; it took nearly half a day to get it done. For one, many rural households are far from the main all-weather road (the NyeriNyahururu main road for Wiyumiririe residents) where most trading centres with grid electricity are located. Rural roads are poorly served by very erratic public vehicles, if any at all, necessitating walking on foot most of the time. When it rains, foot travel is the only option to local trading centres and taking time off from busy farming activities is time better spent.

Secondly, it can cost about US\$2.0 in public transport costs to and fro. However, before the advent of solar energy in such rural areas, this was the only option to keep cell phones charged. So important is this cell phone connectivity with family and friends that most households found the time and costs associated with it. With solar energy availability, most households are very relieved this difficult choice is over. Why cell phones are crucial to rural folks can be judged from Fig. 5 - the ability to keep families connected on a 24-hour basis (stated by $74 \%$ of respondents, $n=129$ ) is a top priority. It appears that few respondents used cell phones for other activities like business, emergencies, social functions or developmental needs. Jacobson (2007) found very similar results.

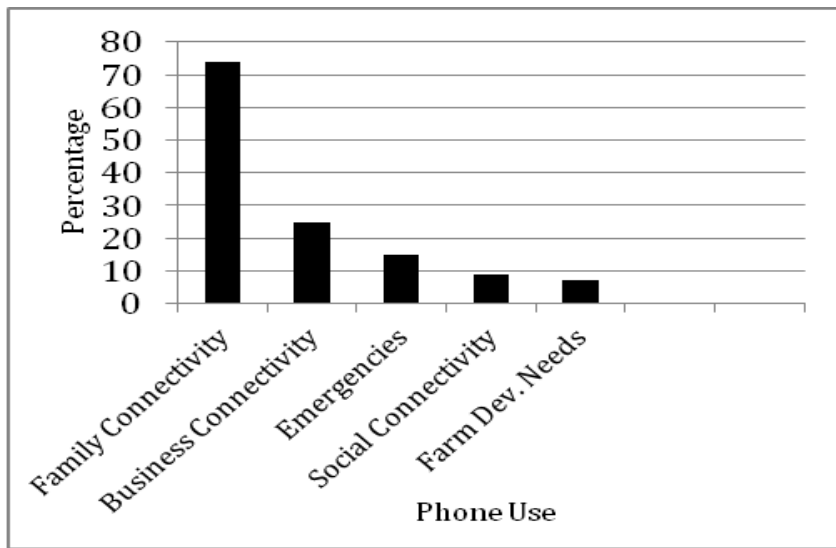

Fig. 5 Household Stated Cell Phone Uses in Wiyumiririe Location $(n=129)$

Table 7.

Solar PV Ranked Priorities in Wiyumiririe Location $(n=129)$

\begin{tabular}{lcc}
\hline Priority & \% Respondents & Rank \\
\hline Household Lighting & 100 & 1 \\
Cellphone Charging & 88 & 2 \\
Radio and TV & 54 & 3 \\
All Other Uses & 12 & 4 \\
\hline
\end{tabular}

Almost half of the households visited (47\%, $\mathrm{n}=129$ ) with school or working children visiting during the holidays stated a near crisis situation in their solar energy usage due to the high demand necessitated by continuous entertainment through radio and TV; and having to charge multiple cell phones each taking at least 2 hours to fully charge the battery. During the cold season when the sky overcast, storing enough power during the day even to charge phones is difficult, leave alone lighting. Such high demand coupled with small capacity solar panels (14-15W range) means that solar power prioritization in such communities is vital. Some respondents stated they have to supplement solar power lighting with kerosene during the cold season. In most cases also sacrifices were made with uses like radio tuning and $\mathrm{TV}$ viewing missing altogether from the daily solar energy budget, which was not always easy during school holidays when younger people are home.

Solar vendors also have small 1-5-3W solar panels specifically for charging cell phones (Table 2). However, because they are relatively expensive compared to slightly more powerful panels, they were not popular with respondents and were found only in $11 \%$ of the households $(n=129)$. As expected, respondents found it more economical to save and purchase a bigger panel that can also provide energy for household lighting.

\section{c) Television and Radio}

Of all households interviewed, at least half of them had access to television (colour or black/white, many between 14-20 inches wide) and 100\% had at least one radio set in the household (Fig. $6 \& 7$ ).

Many homes had more than one radio catering for various rooms in the main house (living room or kitchen and bedroom) or houses outside the main house (for instance for grown-up children visiting). TV viewing, a central evening priority for households owning a set, luckily only consumes $10 \%$ of total household solar energy according to data gathered in this study (Table 7). Primetime TV viewing provides

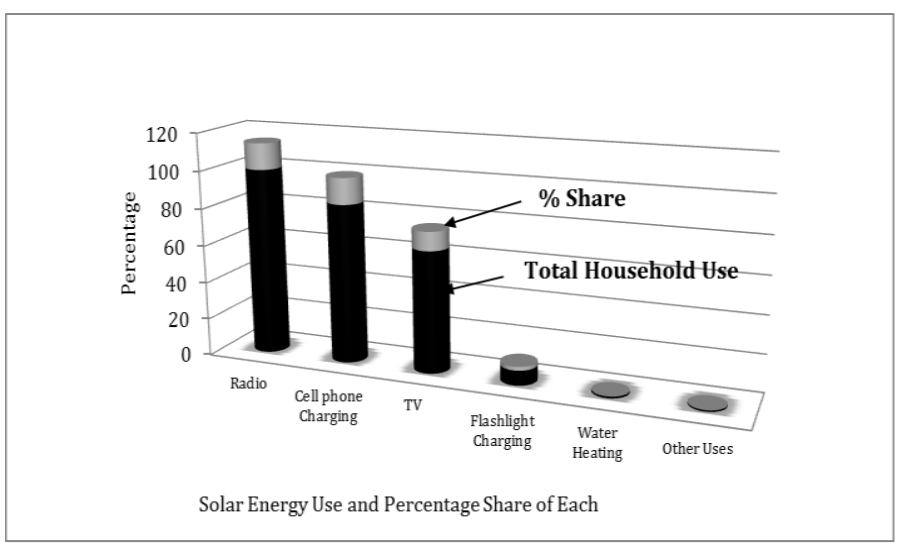

Fig. 6 Household Use of Solar Energy Generated and \% Share of Total in Wiyumiririe Location $(n=129)$ 


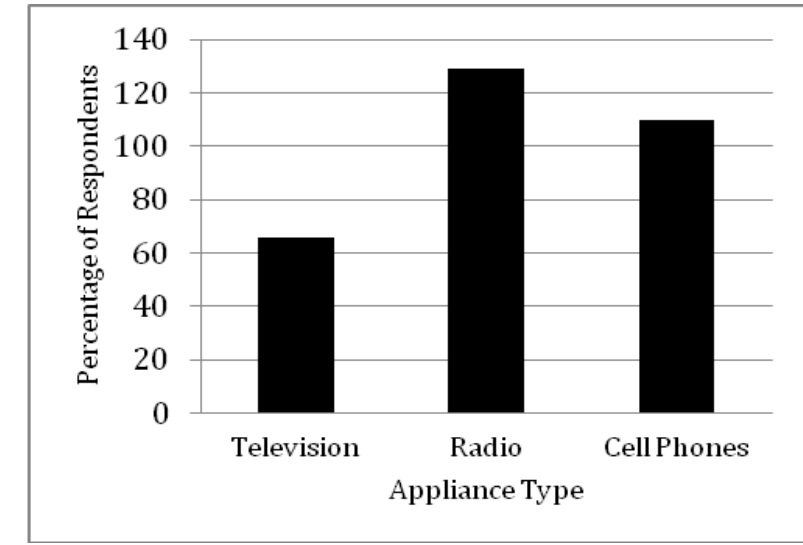

Fig. 7 Numbers of Households with Appliances using Solar Energy in Wiyumiririe Location $(n=129)$

household members national and international news, educational information, information about new products and entertainment, so valued even by rural folks that almost all respondents interviewed stated that (all other things equal), TV viewing was an awaited daily event. Interestingly, while urban folks have access to many TV channels (up to 12 off-the-air), rural folks have access to only one channel - Kenya Broadcasting Corporation, KBC - the oldest one in Kenya fully owned and controlled by the government. Despite this limitation, there is enough programming to keep rural folks informed and entertained. For instance, for five hours (12:30-5:55 am) every morning, the channel airs international news from the BBC in London which due to its timing, is mostly irrelevant and remains largely unviewed by communities in rural areas.

Radio, the favourite news and entertainment source for billions of people worldwide, rural and urban alike, is a crucial resource also found in all households visited in Wiyumiririe (Fig. 6). For many years in Kenya, the state controlled radio programming with only two medium wave (MW) channels available for rural people: the national Kiswahili service and the general English service both operating between 5:30 am until midnight. Staring from the early 1980 s in the capital city Nairobi, broadcasts were also heard in FM. Since the turn of the 21st century, Kenya has seen an explosive growth in radio with many booster stations built in many urban centres around the country. This growth has also seen 24-hour programming, a variety of channels programming not only using the main languages (English and Kiswahili) but also broadcasting in multiple ethnic languages mostly from the capital city, with associated boosters in major towns around the country. This growth in radio was preceded and accelerated by sweeping political reforms that saw the creation of a multi-party democracy in the country in the early 1990s (for many years following independence from Britain in 1963, Kenya remained primarily a single party state with any talk of introducing multiple parties treasonable).
Public radio and TV had morphed into exciting avenues of exchange for ideas, educational information, economic and market conditions, entertainment and news including exposure of many social and economic ills. For rural folks therefore, public radio became an indispensable tool and conduit of up-to-date and much needed societal information. It is no surprise that in many homes visited in this study many landowners owned at least one radio and carried it with them to their farms and other places of work. When working within their homes, household members almost exclusively used solar energy to power their radios. The article by Jacobson (2007) has an excellent coverage of very similar findings on this prime use of solar energy in rural areas.

\section{d) Solar Water Heating, Ironing and Other Uses}

The number of households visited where solar power was used to heat water were negligible $(1 \%$, $\mathrm{n}=129$, Fig. 6). In addition a very small proportion of landowners $(<1 \%)$ expressed the need to use solar energy for purposes such as borehole water pumping for domestic and irrigation purposes and to iron clothes. Hardly surprising, many households understand that using solar energy for these purposes carries with it a big price in solar equipment investment - resources that are hardly available to the majority of landowners. In consideration of these extended solar energy uses, many landowners believed that despite the lengthy waiting, rural grid-based electrification programs were still in place and expected to happen. In fact, some landowners felt the total expense for reasonably adequate solar equipment was more than was required to get their households connected to the grid, but only in the future.

Interestingly, many landowners were so accustomed to SPV that they were unaware of the use of passive solar collectors to warm water for bathing and washing unlike in other rural communities in southern Africa (Ellegård \& Nordström 2001; Leach 2001; Mehlwana 2002; Morales 2002; Rockström et al. 2005; Jacobson 2007; SEI 2007; Chua \& Oh 2012). This however, appears to be dependent on the conditions in the market and their promotional mechanisms of new technologies. A visit to solar equipment outlets in Nyeri town (the provincial headquarters) revealed no such equipment available for public purchase. Contacted vendors stated that there appeared to be no market for them in that part of the country, at least for now. However, in the capital city (Nairobi) passive solar heaters for water heating were available to buyers. The biggest city, very metropolitan and serving as the country's political and financial capital, it is easy to see why. Passive solar collectors also require availability of running water (common in urban settings but uncommon in many rural households), limiting their 
availability to areas where running water is available. In rural areas for now, it appears the increased use of these generally affordable passive solar collectors might require an initial government or non-government promotion and goodwill, and better still more focused market attention and promotion (Kalumiana 2002; Zhao et al. 2013). Adoption by this community of innovative techniques in solar water heating like those routinely used in rural China (Liu et al. 2010) will be a step in the right direction.

\subsection{Landowner Attitudes, Satisfaction, Reliability and Influence towards SPV}

A substantial number of landowners $(88 \%, n=129)$ perceived the use of solar energy most favourably and were pleased with the reliability of the solar energy they were generating (Fig. 8). Only a very small proportion found it "somehow" or "not" reliable (12\%).

This reflects the prevailing positive attitude and opinion amongst many households that solar energy was clean energy requiring very little upkeep and maintenance. Many felt that despite the many limiting factors associated with solar energy (discussed in next paragraph) it was prestigious, clean, secure and a dependable source of energy that could be harnessed forever. They therefore called upon government, nongovernmental organizations, private enterprises (especially oil companies like BP, Chevron and Shell) and donor sectors to extend goodwill to rural communities and find ways in which they can assist them become energy sufficient, particularly in provision of credit opportunities on easy terms and other partnerships. This is the same call made by Barnes and Halpern (2000) calling upon the United States and other rich nations to provide financial tools and incentives to help rural communities producing greater global benefits of reduced greenhouse gases that affect world climates, expanded use of affordable, clean and renewable energy and improved incomes and standards of living for rural communities. Individual nations can also mobilize additional resources (capital, research and education) to support this endeavour (Jacobson 2007; Brent \& Kruger 2009; Brew-Hammond 2010; Mekhilef et al. 2012).

On the other hand, SPV satisfaction rates varied tremendously. While $39 \%$ of respondents were completely or reasonably satisfied, significant majorities (61\%) were unsatisfied (Fig. 9)

This general dissatisfaction could be attributed to several causes. One, although most of the generated solar energy adequately caters for some needs like cell phone charging; it does not meet all the basic needs of many households particularly in lighting and TV viewing. Most landowners visited (72\%) had only 1 or 2 rooms wired (Table 6) and wanted more rooms lighted in the main house or in other structures in the immediate vicinity. Two, in a society where necessity breeds invention with a perceived prevailing belief that "nothing should be fixed or replaced unless it breaks down", a small proportion of landowners (22\%) felt they could get the necessary funds to purchase more efficient high-capacity panels but they did not know what to do with the old panel. This was made worse by the fact that used solar product markets were nonexistent in the area.

Three, due to the very limited uses of the solar energy currently generated in contrast to the many landowner electric needs and priorities, an increasing number of landowners (97\%) felt that the final energy solution for the area will greatly hinge on the future availability of grid-based electricity. Four, solar PV technology appeared to have no long-term "stand alone" reliability to a significant number of landowners (71\%). They believed that it has forever to be supplemented by other energy sources like biomass and petroleum products; a fact borne by the current energy usage in the area and percentage contribution to household energy budgets (Table I). Finally, up to $82 \%$ of landowners visited stated they were not experiencing as much energy savings they expected before installing solar energy, no doubt very frustration to many. This lack of energy savings is attributed to two reasons: the limited household budgets which originally allowed for a minimal investment in low-capacity solar equipment providing power in only 1 or 2 rooms (Table 2) and; solar intensity variation during the year, requiring supplemental energy sources for household lighting.

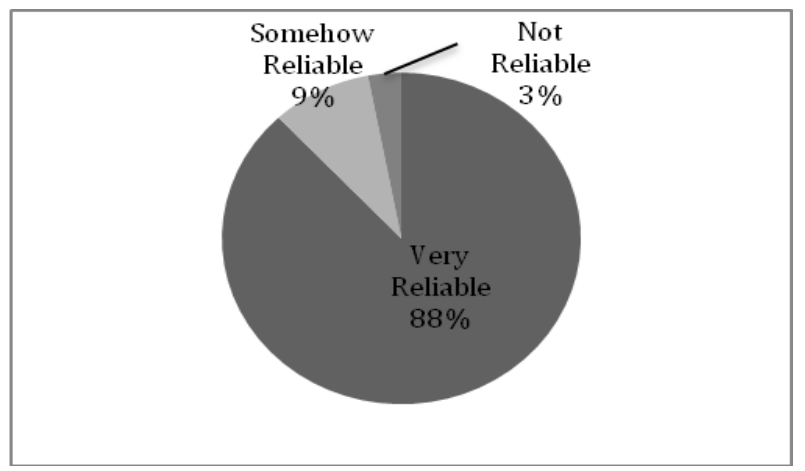

Fig. 8 Solar PV Reliability in Households in Wiyumiririe Location $(\mathrm{n}=129)$

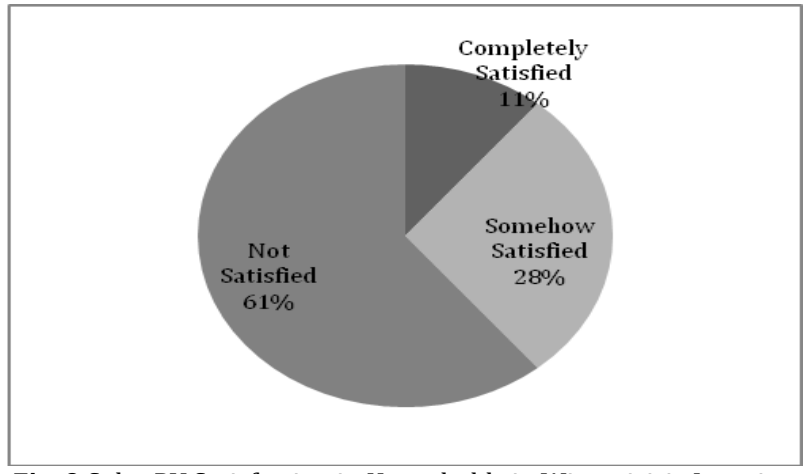

Fig. 9 Solar PV Satisfaction in Households in Wiyumiririe Location $(n=129)$ 


\subsection{SPV Impacts in Region}

In reducing the gaps between energy services available in rural areas compared with urban areas and low-income as compared with high-income households, renewable energy technologies like solar power can make a big difference (Gustavsson 2003; Jacobson 2007; SEI 2007; Brent \& Kruger 2009; Brew-Hammond 2010). While solar PVs remain attractive for decentralized electricity production, the challenge is to find applications that are economically justifiable, socially appropriate and technically sustainable (IEA, 2002). The proportion of landowners who expressed specific developmental initiatives that were closely associated with the availability of solar energy is shown (Fig. 10). Topping the list (91\% of respondents) is improved standard of living for household members. Being far and deep in the rural areas miles away from the nearest all-weather road and visible signs of development (like hospitals, government offices, electricity, running water, post offices, transport facilities, gas stations and social amenities) has traditionally characterized many rural areas classified as remote.

In areas with solar power the availability of electric lighting in households; news and entertainment through radio and $\mathrm{TV}$; and the ability to communicate with family and friends by phone were considered by many respondents visited as good indications of better living styles for most households. It is no surprise that most household members felt better connected with the rest of the world than they were before solar power technology. Morales (2002) found out that people in South Africa, particularly women placed special emphases in the importance of a well-functioning social system with strong moral and ethical base; with many noting key links connecting energy availability and wellbeing including lighting for security, children education, and time savings fetching firewood.

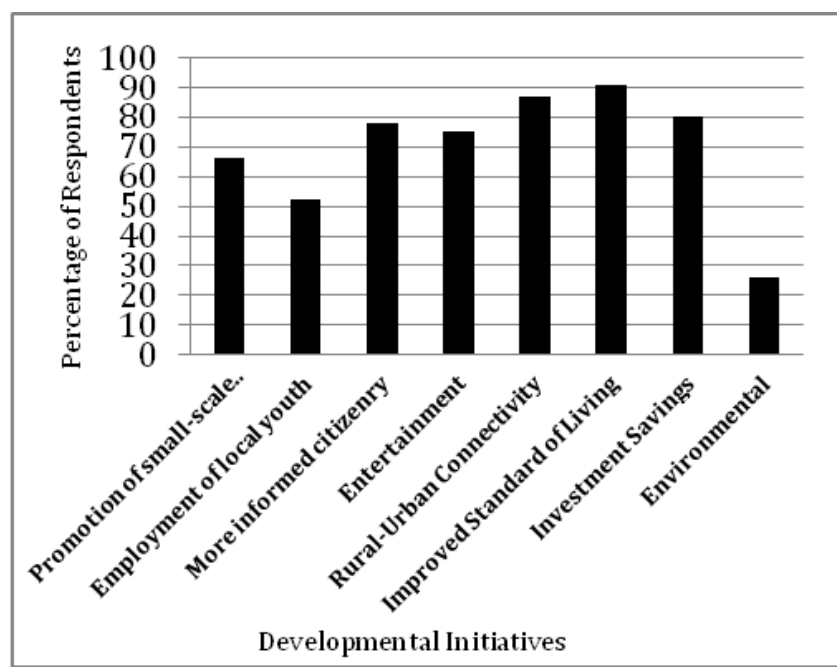

Fig. 10 Developmental Initiatives Associated with Solar PV in Wiyumiririe Location $(n=129)$
A significant proportion (80\%) felt that although they could not account for the income savings, not having to buy kerosene weekly (which costs about US $\$ 0.70$ per litre) was good enough and there were income savings that went into other uses. The invisibility of these savings to most households is not unusual for rural communities - household spending in many rural areas where people are not dependent of a monthly salary, is usually diffuse and unplanned. Many people buy household items as needed because income sources are random and distributed throughout the year from the sale of farm produce, livestock or livestock products like milk or eggs.

About $66 \%$ of the respondents stated solar technology promoted local businesses dealing with solar equipment and other electric services. Those include the development of opportunities like smallscale electrician businesses, medium scale solar equipment and bulb sales, chicken wire sales and solar battery sales (Fig. 10). Many households with solar energy depended on local electricians to do solar installations - safely securing panels on roofs with timber and chicken wire to deter theft; to do household wiring; to secure batteries and to provide any extension services that may be necessary from time to time (e.g. solar panel cleaning with warm soapy water, battery acid flushing and household wiring extensions). Local businesses that sell solar panels and batteries also experience increased equipment sales which improves the local economy. At least $77 \%$ of the households visited stated they obtained their solar equipment from Nyeri town, the provincial headquarters 25 kilometres away or from Nyahururu town located15 kilometres away. The remaining households (23\%) stated their solar equipment were purchased by their working children on their behalf from the state capital, Nairobi, 135 kilometres away or from Nakuru town (Rift Valley provincial headquarters), 65 miles away. Such businesses, half of the respondents thought, promoted local youth graduating from local high schools and colleges of technology thus helping keep them economically productive locally deterring them from relocating to the major urban centres; but more important, away from various petty criminal activities. A study by Stone (1997) found the same in Mexico: "reducing the appeal of urban life by bringing electricity to rural areas is one way solar energy can improve people's lives', p.4). Brent and Kruger present a particularly thought-provoking article on the dilemma nations of Africa face as they try to achieve energy independence in rural areas due to poverty (2009).

A small but significant proportion (26\%, Fig. 10) had experienced savings from solar PV technology in their households that helped protect the environment. This came in form of not cutting trees down for charcoal and firewood in an interesting way. Khennas (2002) notes that cooking from traditional sources has a serious impact on health, and to a lesser extent also 
contributes to deforestation and a potential loss of resource productivity. Many farms have a good number of indigenous trees in the area like Juniperus podicera, Podocarpus falcatus and Mutero; but also introduced trees like Grevilia robusta, Eucalyptus spp. (especially $E$. citriodora, E. globulus, and E. maculata) very useful as sources of building material, fence posts, firewood and charcoal. Respondents stated that before solar PV installation, families spent more time in the kitchen cooking leaving the living room to children to complete their homework using kerosene lanterns. After homework, children usually join their parents in the kitchen to warm up and share the evening meal. Now with solar energy, the well-lighted living room has become more attractive not only for children to do homework, but as a place for the family to relax, listen to the day's news, entertainment programs and video. This means spending less time in the kitchen, therefore less need for charcoal and firewood, in effect, saving trees. Most households visited (74\%) however felt that although they cut down on their firewood usage, they did not experience environmental (in form of charcoal) savings because they were using charcoal-burning jikos for house warming while watching TV in the living room. In fact, some felt they were using more charcoal with solar technology than ever before particularly during the cold season. This important issue requires more investigation. On the other hand, cutting down on kerosene usage for most rural households as a result of the availability of clean alternative energy collectively yields significant environmental savings in form of saved crude oil and combustion gases (that contribute to global warming) and human health savings too in form of reduced household air pollution. As noted by Saghil "indoor and urban air pollution from traditional energy sources and inefficient engines damages the health of millions in developing countries, with enormous cost to families and to the economy" (2002, p.10).

\section{Conclusion}

No society has ever developed without electricity but without doubt, electrification is not development (Leach 2001; Solangi et al. 2011). It appears that while market-based energy initiatives have their place in rural development, as found for this community in Wiyumiririe, they soon approach a "stalled developmental threshold". To expand and maintain growth momentum, a "stalled threshold" has to be jumpstarted with additional resource infusion that will engage more landowners with a common mission of improving their rural livelihoods. As noted by others, available disposable capital seems to play such a prominent role and is most closely associated with solar energy development (Ellegård et al. 2003; Rockström, et al. 2005; Jacobson 2007; Brent \& Kruger 2009; Pandey et al. 2012; Moosavian 2013). As solutions to capital building will not solely rely on subsidies or individual farmer inputs, strategies must be found to mobilize the essential and tested tools for success including sustainable capital generation, building local institutions and capacities that integrate rural people, local participation in rural development activities and public education and training (Pandey et al. 2012). Such tools in Wiyumiririe might take the form of encouraging voluntary savings as the main capital base for rural people, integration of rural markets with national and international markets and bottom-up government and other donor funding approaches aimed at broad-based rural development policies and activities.

\section{Acknowledgement}

This study was funded by the Office of Research and Sponsored Projects (ORSP) and the Department of Health Sciences at the California State University, East Bay. I am very grateful for their financial and logistic support and continued dedication to staff research support and development. I would also like to thank Charles Maingi from the University of Nairobi for assisting me with fieldwork and data analysis. Finally, I would like thank all those landowners in Wiyumiririe who sacrificed many hours of their time to discuss with us about their solar energy programs.

\section{References}

Acker, R.H., Kammen, D.M. (1996) The Quiet (energy) Revolution: Analysing the Dissemination of Photovoltaics Power Systems in Kenya. Energy Policy, 24(1), 81-11.

Abavana, C.G. (2000) Renewable energy for rural electrification: The Ghana initiative. Seminar on Rural Energy Provision in Africa, Nairobi, Kenya.

Abavana, C.G. (2001) The Ghana Renewable Energy Services Project. Experience with PV systems in Africa. UNEP Collaborating Centre on Energy and Environment, 52-55. Roskilde, Denmark.

Arvidson, A. (2004) The Role of Energy in Meeting the MDGs and the Scale of the Challenge. Energy, Environment and Development Series No. 52, Stockholm Environment Institute, Sweden.

Arvidson, A., Kartha, S., Lazarus, M., McGranahan, G., Molares, M. \& de Vylder, S. (1999) Energy Interventions and Poverty Alleviation. Stockholm Environmental Institute, Stockholm, Sweden.

Banks, D. (2003) Photovoltaic System Delivery to Rural Areas Analysis of selected business models. African Solar PV Workshop: Financing Mechanisms and Business Models, May 27-29, Pretoria, UNDPGEF.

Banks, D. \& Karotti, R. (2000) Energy service to rural communities: power, service and profit? Rural Area Power Solutions, Ltd.

Barnes, D.F. \& Halpern, J. (2000) Subsidies and Sustainable Rural Energy Services: Can We Create Incentives Without Distorting Markets? Washington DC, USA, UNDP/World Bank Energy Sector Management Assistance Programme: 12.

Barnett, A. (1995) Do Environmentally Imperatives Present Novel Problems and Opportunities for the International Transfer of Technology? United Nations, New York.

Blaikie, P., Brown, K., Stocking, M., Tang, L., Dixon, P. \& Sillitoe, P. (1997) Knowledge in Action: Local Knowledge as a Development Resource and Barriers to its Incorporation in Natural Resource Research and Development. Agricultural Systems, 55(2), 217-237. 
Bokalders, V. (1994) Rural Lighting - A guide for development workers. Intermediate Technology Publications.

Brent, A.C. \& Kruger, W.J.L. (2009) Systems analyses and the sustainable transfer of renewable energy technologies: A focus on remote areas of Africa. Renewable Energy, 34, 1774-1781.

Brew-Hammond, A. (2010) Energy access in Africa: Challenges ahead. Energy Policy, 38, 2291-2301.

Cabraal, A. \& Cosgrove-Davies, M. (1999) Accelerating Sustainable PV Market Development, Asia Alternative Energy Program (ASTAE). The World Bank, Washington, D.C., USA.

Cabraal, A., Cosgrove-Davies, M. \& Schaeffer, L. (1996) Best Practices for Photovoltaic Household Electrification Programs: Lessons from Experiences in Selected Countries. The International Bank for Reconstruction and Development. The World Bank, Washington, D.C., USA.

Chambers, R. \& Conway, G.R. (1992) Sustainable Rural Livelihoods: Practical Concepts for the 21st Century, Institute for Development Studies, London.

Chaudhuri, A. (1992) Survey Sampling: Theory and Methods. Horst Stenger, New York, NY.

Christensen, J.M. (2001) Foreword. Experience with PV systems in Africa. UNEP Collaborating Centre on Energy and Environment, Roskilde, Denmark.

Chua, S.C. \& Oh, T.H. (2012) Solar energy outlook in Malaysia. Renewable and Sustainable Energy Reviews. 16, 564-574.

Diarra, D.C. \& Akuffo, F.O. (2002) Solar Photovoltaic in Mali: Potential and Constraints. Energy Conversion and Management, 43, 151163.

DME. White Paper on the Energy Policy of the Republic of South Africa. Available from http://www.dme.gov.za/publications/wp_ene/ whitepaper1998.htm Accessed August 22, 2013.

Duke, R D., Jacobson, A. \& Kammen, D.M. (2002). Photovoltaic Module Quality in the Kenyan Solar Home Systems Market. Energy Policy, 30, 477-499.

Ellegård, A. \& Nordström, M. (2001) Rural Energy Service Companies Experiences from Zambia. Stockholm, Stockholm Environment Institute, SEI: 52.

Ellegård, A., Arvidsson, A., Nordström, M., Kalumiana, O. \& Mwanza, C. (2003) Rural People Pay for Solar: Experiences from the Zambia PV-ESCO Project. Paper presented at the ISES 2003, Gothenburg, Sweden.

Gustavsson, M. (2000) Biogas Technology-Solution in Search of Its Problem: A Study of Introduction and Integration of Small-Scale Rural Technologies. Göteborg, Dept of Interdisciplinary Studies, Göteborg University. Retrieved from http://www.he. gu.se/dot/

Gustavsson, M. (2002) Solar Home System Survey 2001 - Survey results from Eastern Province Zambia. Gothenburg, Sweden. (Unpublished manuscript).

Gustavsson, M. (2003) Nigerian Drama and Studies at Night - Impact of Solar Electric Services on User's Livelihood Systems. Paper presented at the ISES 2003, Gothenburg, Sweden, 14-19 June 2003.

Gustavsson, M. \& Ellegård, A. (2002) The impact of solar home systems on rural livelihoods - Experiences from the Nyimba Energy Service Company in Zambia. Renewable Energy (Unpublished manuscript).

Green, G. (2000) Power to the People - Sunlight to Electricity Using Solar Cells. Sydney, University of South Wales Press Ltd.

Hajat, A., Banks, D. Aiken, R. \& Shackleton, C.M. (2009) Efficacy of solar power units for small-scale businesses in a remote rural area, South Africa. Renewable Energy, 34, 2722-2727.

Horlocks, C. (2003) Shell-Eskom Solar home systems in South Africa. African Solar PV Workshop: Financing Mechanisms and Business Models, May 27-29, Pretoria,UNDP-GEF.

International Energy Agency (IEA). (2002) Financing Mechanisms for Solar Home Systems in Developing Countries - The Role of Financing in the Dissemination Process, International Energy Agency Implementing Agreement on Photovoltaic Power Systems: 104.

Jacobson, A. (2004) Connective power: Solar electrification and social change in Kenya. Ph.D. Dissertation, Energy and Resources Group, University of California, Berkeley, USA.
Jacobson, A. (2007) Connective power: solar electrification and social change in Kenya. World Development, 35(1), 144-62.

Kalumiana, 0. (2002) Rural Energy Access: Promoting Solar Home Systems in Rural Areas in Zambia - a Case Study. Paper presented at the WREC, Köln, Germany, 29 June - 5 July.

Khennas, S. (2002) Energy Services and Sustainable Development: a Multi-level Approach. Renewable Energy for Development, 15(1/2), 12. Stockholm Environmental Institute, Stockholm, Sweden.

Kjellström, B. (2005) Renewable Energy Technologies for Decentralised Rural Electricity Services. Renewable Energy for Development, 18(1), 3-5.

Kjellström, B., Katyega, M., Kadete, H., Noppen, D. \& Mvungi, A. (1992) Rural Electrification in Tanzania: Past Experiences - New Approaches. Stockholm Environmental Institute, Stockholm, Sweden.

Kjellström, B., Arvidson, A., Forslund, H. \& Martinac, I. (2005) Report from an International Workshop held in Studsvik, Sweden 10-12 June 2004. SEI Climate and Energy Programme, Stockholm, Sweden.

Leach, G. (2001) Village Power 2000 - PVs against Poverty? Renewable Energy for Development, 14(1), 4-5. Stockholm Environmental Institute, Stockholm, Sweden.

Liu, L., Wanga, Z., Zhang, H. \& Xue, Y. (2010) Solar energy development in China - A review. Renewable and Sustainable Energy Reviews, 14, 301-311.

Louineau, J.P., Dicko, M., Fraenkel, P., Barlow, R. \& Bokalders, V. (1994) Rural Lighting - A guide for development workers, Intermediate Technology Publications.

McGranahan, G. \& Kaijser, A. (1993) Household Energy, Problems, Policies and Prospects. Energy, Environment and Development Series No. 35, Stockholm Environment Institute, Sweden.

Martinot, E. (2001) Renewable Energy Investment by the World Bank. Energy Policy, 29, 689-699.

Martinot, E. \& Cabraal, A. (2001) World Bank/GEF solar home system projects: experiences and lessons learned 1993-2000. Renewable and Sustainable Energy Reviews, 5(1), 39-57.

Martinot, E. \& Ramankutty, R. (2000) The GEF Solar PV Portfolio: Emerging Experience and Lessons. GEF Monitoring and Evaluation Working Paper 2. (Unpublished manuscript).

Mbumwae, V. (1998) National Stakeholders' workshop on renewable energy in Zambia. Held on June 23, 1998, Intercontinental Hotel, Lusaka, Zambia.

Mehlwana, M. (2002) Strategies for a Sustainable Future: A Decade of Rural Electrification in South Africa (1991-2000). Renewable Energy for Development, 15(1/2):1-3. Stockholm Environmental Institute, Stockholm, Sweden.

Mekhilef, S., Safari A., Mustaffa, W.E.S., Saidur, R., Omara, R. \& Younis, M.A.A. (2012) Solar energy in Malaysia: Current state and prospects. Renewable and Sustainable Energy Reviews, 16, 386396.

Mokhutsoane, L. (2001) Lesotho's experience with PV systems. Experience with PV systems in Africa. UNEP Collaborating Centre on Energy and Environment, 23-26. Roskilde, Denmark.

Moosavian, S.M., Rahim, N.A., Selvaraj, J. \& Solangi, K.H.. (2013) Energy policy to promote photovoltaic generation. Renewable and Sustainable Energy Reviews, 15, 44-58.

Morales, M.M. (2002) South African Women on Water, Energy and Food. Renewable Energy for Development, 15(1/2), 6-7. Stockholm Environmental Institute, Stockholm, Sweden.

Mulugetta, Y., Nhete, T. \& Jackson, T. (2000) Photovoltaics in Zimbabwe: Lessons from the GEF Solar Project. Energy Policy, 28, 1069-1080.

Nordstrom, M. (2005) The Bemused Observer - An Interview with Gerald Leach. Renewable Energy for Development, 18(1), 1-2. Stockholm Environmental Institute, Stockholm, Sweden.

Nziramasanga, N. (2001) PV power experience in Zimbabwe. Experience with PV systems in Africa. UNEP Collaborating Centre on Energy and Environment, 15-17, Roskilde, Denmark.

Osuagwu, O. E., Agbakwuru, A. \& Chinedu, P. (2011) Solar power as alternative energy to drive information technology diffusion in Nigeria: a comparative analysis of cost effectiveness of solar over 
thermal energy (solar energy and industrial generators). Journal of Mathematics and Technology, 2(3), 43-47.

Pandey, S., Singh, V.S., Gangwar, N.P., Vijayvergia, M.M., Prakash, C. \& Pandey, D.N. (2012) Determinants of success for promoting solar energy in Rajasthan, India. Renewable and Sustainable Energy Reviews, 16, 3593-3598.

Rockström, J., Axberg, G. N., Falkenmark, M., Lannerstad, M.,Rosemarin, A., Caldwell, A., Arvidson, A . \& Nordström, M. (2005) Sustainable Pathways to Attain the Millennium Development Goals: Assessing the Key Role of Water, Energy and Sanitation. Stockholm Environment Institute, Sweden.

Saghil, J. (2002) The Role of Energy in Sustainable Development. Renewable Energy for Development, 15(1/2), 10-11. Stockholm Environmental Institute, Stockholm, Sweden.

Schaeffer, R.L., Mendenhall III, W. \& Off, L. (1996) Elementary Survey Sampling. 5th ed. Duxbury Press: Belmont, CA, USA.

Scholz, G. (2006) Modern Energy Services and the MDGs in East Africa. Energy, Environment and Development Series, No. 35 (2) Stockholm Environment Institute, Sweden.

Solar Energy International (SEI). (2007) Renewable Energy Education Program. Carbondale, Colorado.
Solangi, K.H., Islam, M.R., Saidur, R., Rahim, N.A. \& Fayaz, H. (2011) A review on global solar energy policy. Renewable and Sustainable Energy Reviews, 15, 249-2163.

Stockholm Environmental Institute. News and Media. Retrieved from http://sei-international.org/ Accessed August 22, 2013.

Stone, L. (1997) Solar Baking under the Sonoran Sun. Home Power, 59, $1-4$

Turyahikayo, G.R. \& Sengendo, M. (2001) Uganda's experience with PV systems. Experience with PV systems in Africa. UNEP Collaborating Centre on Energy and Environment, 32-35. Roskilde, Denmark.

Wade, H. (1997) Solar Photovoltaics for Rural Electrification - What Happened to the Promises?. Renewable Energy for Development, 10(1), 4-6.

Weggoro, N.C. 2006) East African Community Secretariat, Arusha, Tanzania. Renewable Energy for Development, 19(2), 11.

Zhao, Z., Zhang, S.H., Hubbard, B. \&Yao, X. (2013) The emergence of the solar photovoltaic power industry in China. Renewable and Sustainable Energy Reviews, 21, 229-236. 